Original Article

\title{
Prevalence of Trinucleotide Expansions in SCA 17/TBP and JPH3 Genes and Octapeptide Insertion in PRNP Gene in Iranian Patients with Funtington-Disease like Syndrome
}

\author{
Mana Zakeri i id \\ (MSc)Department of Biology, Islamic \\ Azad University, Tehran Medical \\ Branch, Tehran, Iran \\ Amir Hosein Babaei \\ (MSc)Islamic Azad University, \\ Science and Research Branch, Tehran, \\ Iran \\ Mohamad Taghi Akbari \\ (PhD)Tehran Medical Genetic \\ Labratory, Tehran, Iran \\ Shohreh Zare Karizi \\ (PhD) Department of Biology Varamin \\ Pishva Branch, Islamic Azad \\ University \\ Faravarh Khordad Poor Deilamani \\ (PhD) Tehran medical genetics \\ laboratory, Tehran, Iran \\ Corresponding author: Mohamad \\ Taghi Akbari \\ Address: Tehran Medical Genetics \\ Laboratory, Tehran, Iran \\ Tel: +989121598407 \\ Email:akbarimt@gmail.com \\ Received: 2019/08/18 \\ Revised: 2019/11/20 \\ Accepted: 2019/12/4

(c) (7) (3) \\ This work is licensed under a Creative \\ Commons Attribution 4.0 License.
}

DOI: $\underline{10.29252 / \mathrm{mlj} .14 .5 .19}$

\begin{abstract}
Background and objective: Huntington's disease (HD) is an autosomal dominant disorder that mainly affects adults. Although mutations in the IT15 gene have been known as the main cause of the disease, patients with HD like (HDL) syndrome have mutations in genes other than the IT15 gene. In this study, we investigate the frequency of mutations in $S C A 17 / T B P, J P H 3$ and PRNP genes in patients with HDL syndrome.
\end{abstract}

Methods: The frequency of mutations in SCA17/TBP, $J P H 3$ and PRNP genes was studied in 56 patients with HDL phenotype but without trinucleotide expansion in the IT15 gene. DNA was extracted from peripheral whole blood by the salting out method. PCR was performed using specific primers for each gene. PCR products were separated on polyacrylamide gel. Sequencing was performed on some samples to confirm the PCR results.

Results: We found neither trinucleotide expansion in the JPH3 and SCA17, nor octapeptide insertion in the PRNP gene.

Conclusion: Based on the results, Iranian patients with HDL syndrome do not have mutation in the TBP, JPH3 and PRNP genes. However, this result may be due to population differences, rarity of the mutations in the studied genes and the small number of study subjects. Therefore, studies with a larger study population that investigate other mutations, such as point mutations in the mentioned genes may help clarify the exact cause of HDL phenotype in Iranian patients.

Keywords: Huntington's Disease, HDL, JPH3, PRNP, SCA17 


\section{INTRODUCTION}

Huntington's disease (HD) is a progressive neurodegenerative disease which mainly occurs in adults (1). The most important clinical symptoms of the disease include movement disorders, chorea, psychological disorders, epilepsy, mood changes and depression. The average age of onset is between 30 to 50 years; however, 5 to 10 percent of the patients develop the disease before the age of 20, a condition known as the juvenile HD (2).

Huntington's disease is caused by the CAG repeat expansion (poly-glutamine) in the coding region of IT15 (HTT) gene located at 4p16.3. Patients with HD-like (HDL) syndromes have symptoms similar to HD but do not have the trinucleotide expansion in the IT15 gene. There are three HDL syndromes (HDL1, HDL2 and HDL4) with autosomal dominant inheritance and one (HDL3) with recessive inheritance (3).

HDL1 disease or transmissible spongiform encephalopathy (prion disease) is a rare, progressive neurodegenerative disorder that affects one in every $1,000,000$ people annually. The age of onset of HDL1 is $25-45$ years. The symptoms include cognitive difficulties, ataxia and myoclonic seizures, personality changes, psychiatric symptoms, fatigue, emotional numbness, dysarthria, dementia and motor disturbance with chorea $(4,5)$. The disease is caused by the insertion of octapeptide repeats in the PRNP gene, which is located on the short arm of chromosome 20. The octapeptide repeat region lies between codon 51 and 91, which includes a nonapeptide (Pro-Gln- (Glu) 4-Trp-Gly-Gln) followed by an octapeptide (Pro-His- (Gly) 3Trp -Gly-Gln). With each repeat, 24 nucleotides ( 8 amino acids) will be added to the gene. Normally, there are four octapeptide repeats in the PRNP gene. In HDL1 patients, the repeat numbers is increased to $11-13$, which produces an abnormally long cellular prion protein. It is not clear that how abnormal proteins destroy neurons and cause characteristic features of HDL1 (6).

Huntington's disease-like 2 (HDL2) is caused

by CAG/CTG expansion in the $J P H 3$ gene

located at 16q23. Normal and pathogenic alleles have 6-28 and $44-57$ repeats, respectively. Alleles with $29-40$ repeats are unstable (7).
The disease usually appears at the age of 29 to 41 and has a 10 to 20 years survival time. Clinical symptoms of the disease include hypokinesia (rigidity, bradykinesia), tremor, dysarthria, psychological symptoms, emotional and cognitive abnormalities, convulsion and chorea. HDL2 is a rare and most commonly observed in Africa (8).

Huntington's disease-like 4 (HDL4), also known as spinal cerebellar ataxia type 17 (SCA17), is caused by a mutation in the TATA-binding protein $(T B P)$ gene, which is located at 6q27 and contains eight exons. The CAG/CAA repeats are located in exon 3 of this gene. Normal alleles have 25-42 CAG/CAA repeats. The pathogenicity of alleles with 43 and 44 repeats is uncertain. Furthermore, alleles with up to 49 repeats have incomplete penetrance $(9,10)$. Main symptoms of HDL4 include uncoordinated movement, dementia, involuntary movement, psychosis, seizure and rigidity. The age of onset (3-75 years) and clinical presentation are extremely variable (11).

HDL3 is mapped to $4 \mathrm{p} 15.3$ and has recessive inheritance. The responsible gene for this disease is not known (12).

In HDL syndromes, the repeat number is significantly correlated with early onset and disease severity (13). The aim of this study was to evaluate frequency of the mentioned mutations in the TBP, JPH3 and PRNP genes of patients with HDL syndromes.

\section{MATERIALS AND METHODS}

In this study, we investigated the expansion of trinucleotide repeats in the $\mathrm{JPH} 3$ and $S C A 17 / T B P$ genes and the insertion of octapeptide repeats in the PRNP gene. We recruited 56 unrelated HDL patients (34 men and 22 women, mean age: $52 \pm 5$ years) with normal trinucleotide repeat numbers in the IT15 gene, who were referred to the Tehran Medical Genetics Laboratory between 2006 and 2010. Written consent was obtained from patients or their guardians.

DNA was extracted from peripheral whole blood using the salting-out method. The quantity and quality of the extracted DNA was assessed by a spectrophotometer (Nanodrop 2000c, Thermoscientific) (14). Three primer pairs were designed to amplify the region of interest of each gene (Table 1). 
Table 1. Sequence of the primers used for amplification of the JPH3, PRNPand TBPgenes

\begin{tabular}{ccc}
\hline Primer & \multicolumn{1}{c}{ Sequences $\left(\mathbf{5}^{\prime} \rightarrow \mathbf{3}^{\prime}\right)$} & $\begin{array}{c}\text { Product } \\
\text { length }\end{array}$ \\
\hline JPH3-F & AATCGATCTGTGCCTTCATTC & $\mathbf{1 3 9}$ bp \\
JPH3-R & GTTCCCTGCACAGAAACCATC & \\
PRNP-F & AAGCCTGGAGGATGGAACAC & $\mathbf{2 3 3} \mathbf{b p}$ \\
PRNP-R & TTACTCGGCTTGTTCCACTGAC & \\
SCA17-F & CCTTATGGCACTGGACTGAC & $\mathbf{2 4 5}$ bp \\
SCA17-R & GTTCCCTGTGTTGCCTGCTG & \\
\hline
\end{tabular}

Amplification was done using the Veriti 96 well Thermal Cycler (Applied Biosystems) with the following conditions: initial denaturation at $95{ }^{\circ} \mathrm{C}$ for $5 \mathrm{~min}$, followed by 32 cycles of $94{ }^{\circ} \mathrm{C}$ for $40 \mathrm{sec}, 65^{\circ} \mathrm{C}$ for $40 \mathrm{sec}$, $72{ }^{\circ} \mathrm{C}$ for $40 \mathrm{sec}$ and final extension at $72{ }^{\circ} \mathrm{C}$ for $10 \mathrm{~min}$. PCR products were separated on $12 \%$ polyacrylamide gel stained with silver nitrate. Also, for determining the exact number of repeats, several samples from the studied genes were sequenced by Macrogen Co. (South Korea).

\section{RESULTS}

In this study, all patients had normal repeat numbers (Figures 1-3). The average repeat numbers for the JPH3 and TBP genes was 1315 and 33-35, respectively. In addition, the average number of octapeptide repeats in the PRNP gene was 3-4.

Figure 4 shows an example of the $P R N P$ gene sequencing result in one of the patients using the forward primer.

Figure 1. PCR products of the PRNPgene amplification on 12\% polyacrylamide gel. Columns 1 to 6: HDL patients, column 7: normal control sample, M: 50 bp size marker

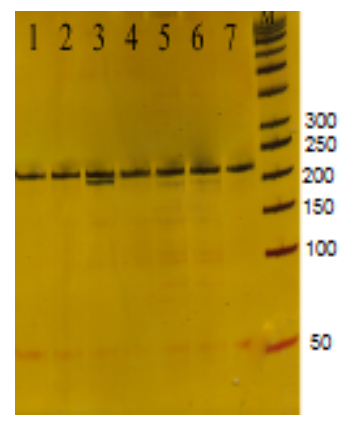

Figure 2. PCR products of the $\mathrm{JPH} 3$ gene amplification on $12 \%$ polyacrylamide gel. Columns 1 to 6: HDL patients, column 7: normal control sample, M: 50 bp size marker.

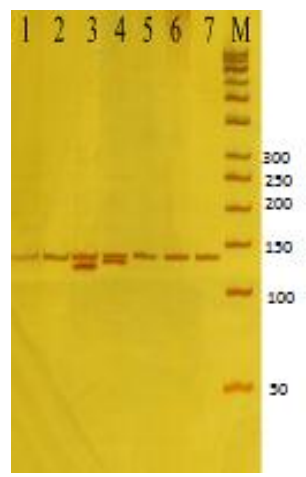


Figure 3. PCR products of the TBPgene amplification on 12\% polyacrylamide gel. Columns 1 to 6: HDL patients, column 7: normal control sample, M: 50 bp size marker.

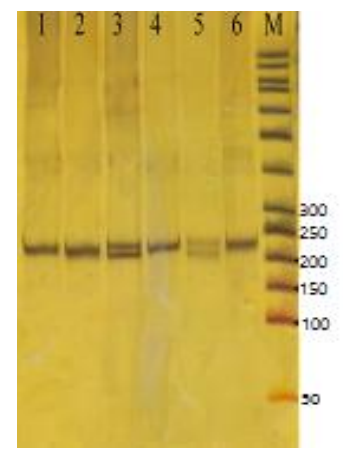

Figure 4. Sequencing result of octapeptide region in the PRNPgene using the forward primer.

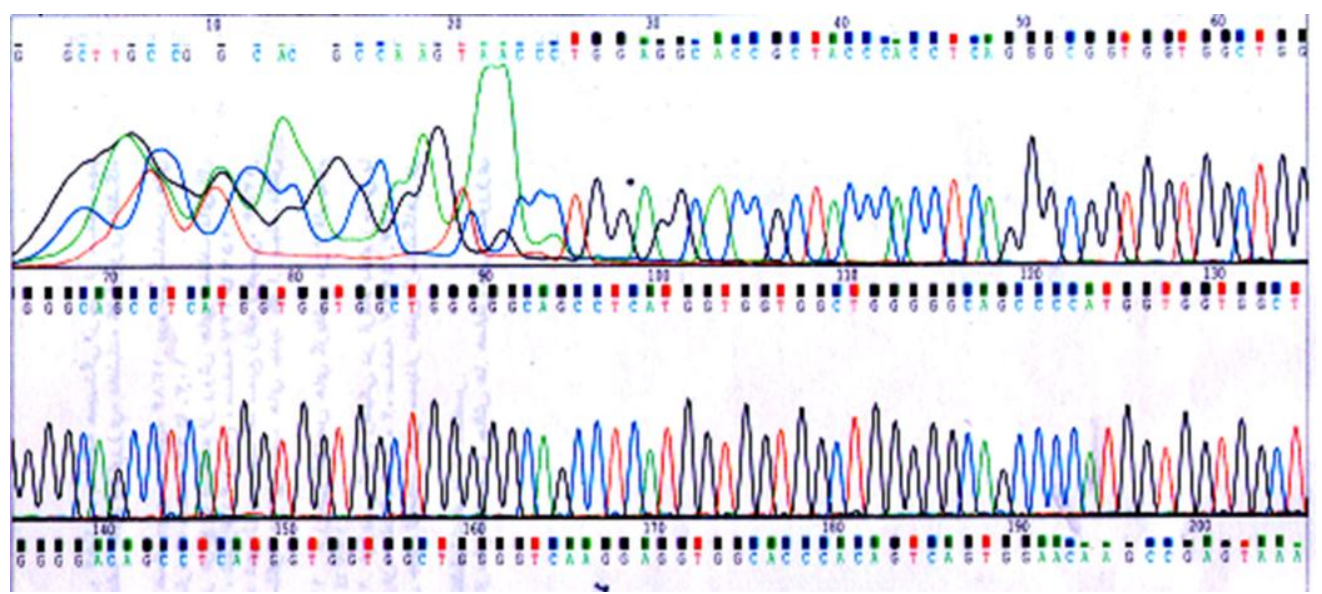

\section{DISCUSSION}

Huntington's disease and HDL syndromes are autosomal dominant disorders (except for HDL3) characterized by progressive neurodegeneration, cognitive impairment and behavioral abnormalities that occur in adulthood. In 1993, abnormality in the IT15 (HTT) gene was identified as the causative agent for HD $(15,16)$. However, it was found that a number of patients with clinical symptoms of HD do not have a three nucleotide expansion in their IT15 gene. Later, other genes such as PRNP, JPH3, SCA17 and $D R P L A$ were found to be responsible for HDL symptoms.

In this study, $56 \mathrm{HDL}$ patients with no mutation in the IT15 gene were studied for $J P H 3, P R N P$ and TBP genes abnormality. No trinucleotide expansion or octapeptide insertion was found in the subjects. In a study on 106 Brazilian patients, 37 and 29 patients were affected by HD and HDL syndromes, respectively. Moreover, $10.3 \%$ of the HDL patients had mutations in the $\mathrm{JPH} 3$ gene and were therefore diagnosed with HDL2 (17). In a study in America on 538 patients with HDL phenotypes, six patients had mutations in the JPH3 gene. In Japan, no patient had JPH3 mutation (18). In Serbia and Montenegro, 198 HDL patients were studied for CTG repetition expansion in the JPH3 gene using PCR and sequencing. It was revealed that alleles had 1118 CTG repeats, so HDL2 is very rare in these populations (19). Some studies have proposed other genes as candidate for HDL diagnosis. For instance, CREBBP and POU $3 F 2$ genes were studied in Portuguese patients and there was no mutation in the genes. In Japan, mutation in the DRPLA gene was common among HDL patients (20). Table 2 summarizes a number of studies that have been performed on these genes in different populations. 
Table 2. Frequency of HDL syndromes in different populations

\begin{tabular}{|c|c|c|c|c|}
\hline $\begin{array}{l}\text { Year of } \\
\text { study }\end{array}$ & Study population & $\begin{array}{c}\text { Number } \\
\text { of subjects }\end{array}$ & Studied genes & Frequency of mutations \\
\hline 1999 & $\begin{array}{l}\text { America and Britain } \\
\text { (13) }\end{array}$ & 15 & $S C A 1,2$ and 3 and $D R P L A$ & 0 \\
\hline 2001 & $\begin{array}{c}\text { African Americans } \\
\text { (13) }\end{array}$ & 330 & $H D L 2$ & $1.2 \%$ \\
\hline 2002 & $\begin{array}{c}\text { Germany and Austria } \\
\text { (14) }\end{array}$ & 1600 & $\begin{array}{l}\text { SAC17 } \\
\text { HDL2 }\end{array}$ & $\begin{array}{c}9(0.005 \%) \\
0\end{array}$ \\
\hline 2003 & France $(8)$ & 252 & $H D L 1, H D L 2, S C A 17$ and $D R P L A$ & $\begin{array}{l}\text { HDL2 }=2(33 \%) \\
\text { SCA17 }=2(33 \%)\end{array}$ \\
\hline 2004 & North America (13) & 538 & $H D L 2$ & 6 \\
\hline 2005 & Yugoslavia (16) & 48 & DRPLA,23,17,SCA1,HDLA1,HDL2 and NFP & 0 \\
\hline 2007 & South Africa (17) & 50 & HDL2 & $15(30 \%)$ \\
\hline 2006 & Portugal (18) & 107 & $S C A 17, D R P L A, N F P, H D L 1$ and $H D L 2$ & 0 \\
\hline 2008 & England (5) & 258 & $D R P L A, 17,23, S C A 1, H D L 1, H D L 2, F R D A$ and $N F P$ & $\begin{array}{l}\text { SCA17 }=5(1.8 \%) \\
\text { HDL1 }=1(0.4 \%) \\
\text { FRDA }=1(0.4 \%) \\
\text { HDL2 }=1(0.4 \%)\end{array}$ \\
\hline 2008 & Poland (19) & 224 & DRPLA,SCA17 and HDL2 & $\operatorname{SCA} 17=1(0.44 \%)$ \\
\hline 2011 & Brazil (12) & 29 & ChAC,DRPLA,17,23,SCA1 and HDL2 & $\begin{array}{c}\text { HDL2 }=3(10.3 \%) \\
\text { ChAC }=2(6.8 \%)\end{array}$ \\
\hline 2014 & $\begin{array}{l}\text { Iran (the present } \\
\text { study) }\end{array}$ & 56 & $H D L 1, H D L 2$ and $H D L A$ & $\begin{array}{l}\text { HDL1 }=0 \\
\text { HDL2 }=0 \\
\text { HDL4 }=0\end{array}$ \\
\hline
\end{tabular}

\section{CONCLUSION}

......We found no mutation in the TBP, JPH3 and PRNP genes of patients with HDL syndromes. However, this result may be due to population differences, rarity of the mutations in the studied genes and the small number of study subjects. Therefore, studies with a larger study population that investigate other mutations, such as point mutations in the mentioned genes may help clarify the exact cause of HDL phenotype in Iranian patients.

\section{ACKNOWLEDGEMENTS}

......The authors would like to thank the personnel of Tehran Medical Genetics Laboratory for their assistance and support.

\section{CONFLICT OF INTEREST}

......There is no conflict of interest regarding publication of this article.

\section{REFERENCES}

1. Margolis RL, Ross CA. Diagnosis of Huntington Disease. Clinical Chemistry. 2003; 49(10): 1726-1732.

2.Ross CA, Aylward EH, Wild EJ, Langbehn DR, Long $\mathrm{JD}$, Warner $\mathrm{JH}$, et al. Huntington disease: natural history, biomarkers and prospects for therapeutics. Nat Rev Neurol. 2014; 10(4): 204-16.

3.Warby SC, Graham RK. huntingtons disessase. Initial posting. 1998.

4.Paucar M, Xiang F, Moore R, Walker R, Winnberg E, Svenningsson P. Genotype-phenotype analysis in inherited prion disease with eight octapeptide repeat insertional mutation. Prion. 2013; 7(6): 501-510.
5. Holmes SE, O'Hearn E, Rosenblatt A, Callahan C, Hwang HS, Ingersoll-Ashworth RG, et al. A repeat expansion in the gene encoding junctophilin-3 is associated with Huntington disease-like 2. Nat Genet. 2001; 29(4): 377-8.

6.Puckett C, Concannon P, Casey C, Hood L. Genomic structure of the human prion protein gene. Am J Hum Genet. 1991; 49(2): 320-329.

7.Stevanin G, Fujigasaki H, Lebre AS, Camuzat A, Jeannequin C, Dode C, et al. Huntington's disease-like phenotype due to trinucleotide repeat expansions in the TBP and JPH3 genes. Brain 2003; 126(7): 1599-603.

8.Margolis RL, Rudnicki DD, Holmes SE. Huntington's Disease like-2: Review and Update. Acta Neurol Taiwan. 2005; 14(1): 1-8.

9.Nakamura K, Jeong SY, Uchihara T, Anno M, Nagashima K, Nagashima T, et al. SCA17, a novel autosomal dominant cerebellar ataxia caused by an expanded polyglutamine in TATA-binding protein. Hum Molec Genet 2001; 10: 1441-1448.

10.Imbert G, Trottier Y, Beckmann J, Mandel JL. The gene for the TATA binding protein (TBP) that contains a highly polymorphic protein coding CAG repeat maps to 6q27. Genomics. 1994; 21(3): 667-8.doi: 10.1006/geno.1994.1335.

11.Shimojo Y, Osawa Y, Fukumizu M, Hanaoka S, Tanaka H, Ogata F, et al. Severe infantile entatorubral pallidoluysian atrophy with extreme expansion of CAG repeats. Neurology. 2001; 56(2): 277-278.

12.Schneider SA, Walker RH, Bhatia KP. The huntingtons disease-like syndrome what to consider in patient with a negative huntingtones like disease gene test. Nat Clin Pract Neurol. 2007; 3(9): 517-25.doi: 10.1038/ncpneuro0606. 
13.Puckett C, Concannon P, Casey C, Hood L. Genomic structure of the human prion protein gene. Am J Hum Genet. 1991; 49(2): 320-329.

14.Miller SA, Dykes DD, Polesky HF. A simple salting out procedure for extracting DNA from human nucleated cells. Nucleic Acids Res. 1988; 16(3): 1215-1220.

15.Holmes SE, O'Hearn E, Rosenblatt A, Callahan C, Hwang HS, Ingersoll-Ashworth RG, et al. A repeat expansion in the gene encoding junctophilin-3 is associated with Huntington disease-like 2. Nat Genet 2001; 29(4): 377-8.

16.Stevanin G, Fujigasaki H, Lebre AS, Camuzat A, Jeannequin C, Dode C, et al. Huntington's disease-like phenotype due to trinucleotide repeat expansions in the TBP and JPH3 genes. Brain. 2003; 126(7): 1599-603.
17.Rodrigues GR, Walker RH, Bader B, Danek A, Brice $\mathrm{A}$, Cazeneuve $\mathrm{C}$, et al. Clinical and genetic analysis of 29 Brazilian patients with Huntington's disease-like phenotype. Arq Neuropsiquiatr. 2011; 69(3): 419-23. doi: 10.1590/S0004-282X2011000400002.

18. Margolis RL, Holmes SE, Rosenblatt A, Gourley L, Hearn EO, Ross CA. HDL2 in north American and japan. Ann Neural. 2004; 56(5): 570-674. DOI: 10.1002/ana.20248.

19.Keckarević M, Savić D, Romac S. JP-3 gene polymorphism in a healthy population of Serbia and Montenegr. Journal of Genetics. 2005; 84(1): 69-71.

20.Schneider SA, Walker RH, Bhatia KP. The Huntington's disease-like syndromes: what to consider in patients with a negative Huntington's disease gene test. Nat Clin Pract Neurol. 2007; 3(9): 517-25. doi: 10.1038/ncpneuro0606.

\section{How to Cite:}

Zakeri M, Babaei AH, Akbari MT, Zare Karizi SH, Khordad Poor Deilamani F. [Prevalence of Trinucleotide Expansions in SCA17/TBP and JPH3 Genes and Octapeptide Insertion in PRNP Gene in Iranian Patients with Huntington-Disease like Syndrome]. mljgoums. 2020; 14(5): 19-24. DOI: $10.29252 / \mathrm{mlj} .14 .5 .19$ 